\title{
Fear of floating or fear of inflation? The role of the exchange rate pass-through
}

\author{
Armando Baqueiro, Alejandro Díaz de León and Alberto Torres, ${ }^{1}$ \\ Bank of Mexico
}

\begin{abstract}
This paper examines the exchange rate pass-through in the transition to low and stable inflation environments. The purpose is to test if low and stable inflation environments lead to low levels of exchange rate pass-through and thus contribute to weakening the "fear of floating" phenomenon experienced by some small open economies. The results presented are in line with this hypothesis. For a group of small open economies, which have recently experienced an inflation reduction process, it is shown that the level of exchange rate pass-through weakens as the level of inflation falls. Therefore, it is argued that once nominal variables are stable, the "fear of inflation", which any central bank should have, no longer implies a "fear of floating".
\end{abstract}

\section{Introduction}

This paper examines the exchange rate pass-through in the transition to low and stable inflation environments. The purpose is to test if such environments lead to low levels of exchange rate passthrough and thus contribute to weakening the "fear of floating" phenomenon experienced by some small open economies. It is argued in the debate between "hard pegs" and "floats" that the stability of nominal variables, among other issues, should play a key role since it affects the strength of exchange rate pass-through and thus the immediate benefits of flexible exchange rate arrangements.

Over a number of years small open economies have been affected by external shocks such as volatile capital flows. The consequences have not been mild and therefore the debate over which set of policies is most effective in containing the potentially perverse effects of such types of shocks has been revisited. In this debate there is consensus about the importance of price and financial stability, strict financial regulation and sound fiscal policy. However, at the centre of this debate there is still a controversy over the best exchange rate regime available. This specific question is particularly relevant for emerging market economies.

The case of Mexico is interesting since the country is still in the process of consolidating its macroeconomic stability, ie in the transition to a low and stable inflation environment. However, another factor has contributed to putting the Mexican case at the centre of this debate. Over the last two decades the economy has experienced large exchange rate depreciations and high inflation. Not surprisingly the level of exchange rate pass-through in Mexico has been high and thus exchange rate depreciations are likely to cause inflationary pressures. In the light of this record one would expect that limited exchange rate flexibility would best contribute to the inflation reduction process. However, the flexible exchange rate arrangement in recent years has proven successful in lowering the inflation rate, providing macroeconomic stability.

\footnotetext{
The authors are grateful for helpful comments from Daniel Garcés, Julio Santaella, participants in the European Central Bank's Preparatory Workshop for the Madrid Seminar of the Eurosystem and Latin American Central Banks in 2002, participants in the Bank for International Settlements' Autumn 2002 Central Bank Economists' Meeting and Daniel Sámano, who also provided excellent research assistance. The opinions expressed in this article are solely those of the authors and do not necessarily represent the point of view of the Bank of Mexico. Correspondence: abaqueiro@banxico.org.mx, adiazl@ banxico.org.mx and atorres@banxico.org.mx.
} 
The issue that motivates the analysis presented in this paper is that, in the debate between "hard pegs" and "floats" for small open economies, the inflation environment has not received attention as one of the key elements in the debate. A hypothesis recently discussed in the literature states that the level of the exchange rate pass-through depends on the inflation environment, ie as the inflation environment becomes stable, characterised by a low inflation rate and competitive markets, the strength of the pass-through weakens. ${ }^{2}$ This statement implies that only when price stability is achieved can the benefits of a floating regime fully materialise since the low level of exchange rate pass-through diminishes the "fear of floating" phenomenon.

To address this hypothesis, the paper is organised as follows. Section 2 presents a brief review of some of the issues in the old debate on fixed versus flexible exchange rate regimes and shows that in recent times the debate has been polarised between the extremes of "hard pegs" and "pure floats". The evidence reviewed shows that there is no consensus as to which arrangement produces better macroeconomic performance. Section 3 reviews the arguments that have recently been used against the convenience of flexible exchange rates in economies which face difficulties in allowing the exchange rate to move freely. These arguments are then used to identify one of the key elements in the "fear of floating" hypothesis: the exchange rate pass-through. Section 4 analyses the relationship between the exchange rate pass-through and the inflation environment in a group of small open economies with flexible exchange rate regimes and which have moved to low-inflation environments in recent years. Section 5 concludes.

\section{The debate on fixed versus flexible exchange rate regimes}

One of the oldest debates in economic literature is the one regarding exchange rate arrangements. Many papers have been written on this subject and the basic elements of the debate appear in textbooks on international economics. Among those studies, Edwards (2002a, 2002b) and Velasco (2002) present recent reviews of the debate.

Traditionally the main argument in favour of flexible exchange rate arrangements is that monetary policy is not constrained by the predetermined level of the exchange rate. Thus, monetary policy sets interest rates in order to achieve domestic equilibrium (ie price stability) while the nominal exchange rate adjusts to balance the external accounts. Under this regime monetary policy itself is the nominal anchor of the economy and, once price stability has been achieved and is expected to be maintained, interest rates can be set by the monetary authorities in order to smooth the business cycle: a countercyclical monetary policy is then an option. Another point in favour of flexible exchange rates is that whenever the economy is hit by an adverse shock to the terms of trade, the requisite real exchange rate depreciation is achieved faster by allowing the nominal exchange rate to depreciate rather than by waiting for the domestic price level to decrease. It is also argued that a flexible exchange rate allows interest rates to be less volatile and thus the real sector is better protected against external shocks.

On the other side of the debate, the main argument in favour of fixed exchange rates is that this arrangement fosters credibility in economic policies by imposing an automatic mechanism that regulates the amount of money and thus sets interest rates accordingly. Fixing the exchange rate implies abandoning an independent monetary policy but it also means that the monetary policy from the other country, with its credibility, is imported. Another advantage of this arrangement is that the role of the nominal exchange rate as the nominal anchor of the economy is easier for the public to understand than the more abstract concept of monetary policy being the anchor. As a result, price stability is, in theory, achieved faster.

The traditional reasoning in favour of one or the other regime used to be expressed in terms of price rigidities and the exposure of the economy to terms-of-trade shocks. An economy in which a large component of exports is commodities has a large exposure to such shocks and therefore could benefit more by allowing the nominal exchange rate to absorb them. Conversely, if the exposure to external

\footnotetext{
See Taylor (2000) and Devereux and Engel (2001).
} 
shocks is not an important issue, then the economy could be best served by the stability provided by a fixed exchange rate.

The debate at a theoretical level has always been centred on the two pure regimes: flexible versus fixed. However, in practice, countries have adopted arrangements which combine features of both, so that, in most countries, the actual exchange rate regime lies in between the extremes of "pure floats" and "hard pegs". A classic example is the setting of exchange rate bands, where the exchange rate is allowed to fluctuate within a certain range but is not allowed to move beyond the band's limits. However, in recent times several countries have modified their exchange rate policy and have moved towards the extremes and thus formed what is now known as the bipolar view. ${ }^{3}$ On the one hand, the increased role of transparency of economic policy and the effective communication device that inflation targeting provides has triggered shifts towards more flexible exchange rate regimes. In addition, different types of "dirty floats" have become closer to "pure floats" as currency markets deepen and the effectiveness of foreign exchange intervention is questioned. On the other hand, the importance of credibility in the sustainability of the exchange rate regime has pushed some countries in the opposite direction, towards fixed exchange rates. In some cases the "soft pegs" have been transformed into "hard pegs" (ie currency boards and dollarisation).

So far the empirical evidence has not been conclusive on which regime produces better macroeconomic performance. Edwards (1993) analyses evidence from developing countries during the 1980s which suggests that countries with fixed exchange rates experience lower inflation rates than countries that float. The study argues that one reason for this result is that fixed exchange rates impose more discipline on monetary authorities. However, in another study Ghosh et al (1995) find that for upper middle-income countries exchange rate flexibility is not associated with higher rates of inflation. Their finding suggests that among these countries "hard pegs" and "pure floaters" experience lower inflation rates than "intermediate floaters". With respect to output performance, the evidence has also not been conclusive. A study by the IMF (1997) shows that for the period 1975-96 there are no significant differences between GDP growth rates experienced by countries under either of the two types of exchange rate regime. Furthermore, Levy-Yeyati and Sturzenegger (2002) find that for developing countries less flexible exchange rate regimes are associated with slower output growth and greater output volatility, while for industrial countries the exchange rate regime does not appear to have a significant impact on growth.

The above suggests that the debate on fixed versus flexible exchange rate regimes is not only unsettled but has recently been further polarised between the extremes of "hard pegs" and "pure floats" (bipolar view). Furthermore, newly available evidence on the macroeconomic performance of countries with different exchange rate arrangements seems to provide no clue as to the direction the debate will follow in the future, not least because macroeconomic performance is also determined by other important factors such as fiscal policy. Since it can be argued that unsound fiscal policy dominates over monetary and exchange rate policy in many developing economies, direct comparisons of the performance of different foreign exchange rate arrangements become more difficult.

\section{Recent criticism of flexible exchange rates}

As mentioned before, it is well known that under a flexible exchange rate regime monetary policy is independent of exchange rate policy. That is, interest rates could be set to achieve price stability while at the same time the nominal exchange rate could adjust in order to attain equilibrium in the external accounts. However, several authors have argued that, for small open economies which face difficulties in letting the nominal exchange rate adjust freely, an independent monetary policy is not a feasible option. These arguments have been proposed mainly by Calvo and Reinhart (2002) with the "fear of floating" hypothesis and by Eichengreen and Hausmann (1999) with the "original sin" hypothesis. They argue that the textbook advantages of a pure float are not attainable in emerging markets due to lack of credibility in their institutions. Therefore, since the problem is endemic in their view, these countries should adopt "hard pegs" to solve the credibility problem.

3 See Fischer (2001). 
The basic argument against a flexible exchange rate regime is based on the hypothesis that for some countries nominal exchange rate depreciations have negative effects and, consequently, although their exchange rate is flexible in theory, in practice they try to minimise exchange rate movements. The immediate implication of this argument is that monetary policy is effectively constrained and plays an accommodating role to achieve exchange rate stability. In this case the flexible exchange rate arrangement becomes a de facto peg, that is a "soft peg". Then, the argument goes, the valid comparison is not between "hard pegs" and "floats" but between "hard pegs" and "soft pegs". Finally, between these two options the credibility issue favours the choice of "hard pegs".

The key element in the previous argument is to understand why depreciations have negative effects and therefore are to be avoided by monetary authorities. There are two main reasons for this. First, the "original sin" hypothesis suggests that depreciations are costly in countries where economic agents are unable to borrow long-term domestically and cannot borrow abroad in their own currency, and are thus forced to borrow in foreign currency. In this case the currency exposure restricts the ability of monetary policy to accommodate a negative terms-of-trade shock through a nominal depreciation and thus drives up interest rates. ${ }^{4}$ A second reason for which monetary authorities may choose not to let the exchange rate depreciate is when there is a high level of pass-through from the nominal exchange rate to the domestic price level. In this case the main problem is that the authorities are inclined to minimise the effect of the adverse shock on the domestic price level by raising interest rates and not allow the exchange rate to depreciate. As mentioned above, in these circumstances the formally flexible exchange rate arrangement ends up as a de facto "soft peg".

Recently some authors have presented empirical evidence which suggests that in some countries the nominal exchange rate presents remarkable stability while officially it is said to float freely. Calvo and Reinhart (2002) conclude that in most countries with official flexible exchange rates monetary policy is set in order to minimise the volatility of the nominal exchange rate. Their conclusion is supported by a cross-sectional analysis of the volatility of interest rates, monetary aggregates, international reserves, commodity prices and nominal exchange rates in a set of 153 countries. They find that exchange rate volatility in countries that claim to float is smaller than that of more committed floaters such as the United States. Their conclusion that this has been the result of deliberate policy is based on their finding that the volatility of interest rates, monetary aggregates and international reserves is higher than that observed in the traditional floaters.

In another study, Hausmann et al (1999) analyse the performance of some Latin American countries, again using cross-sectional analysis. They conclude that flexible exchange rate regimes have not been able to provide the benefits that an independent monetary policy should bring. Their evidence suggests that, in some of the Latin American countries with flexible exchange rates, it has been necessary to allow large swings in interest rates in order to keep the inflation rate under control. This policy, they argue, has resulted in higher and more volatile real interest rates, smaller financial systems, wage indexation, more sensitivity of domestic interest rates to international interest rates and a procyclical monetary policy.

From the previous arguments it is clear that one of the key issues behind the "fear of floating" criticism of flexible exchange rates is the level of exchange rate pass-through. In the following section it is argued that the inflation environment should be considered when analysing alternative exchange rate regimes since it directly influences the level of exchange rate pass-through and thus the evaluation of flexible exchange rate arrangements.

\section{Exchange rate pass-through and the transition to low and stable inflation environments}

As mentioned in the previous section, the basic argument against flexible exchange rate arrangements is that if they do not provide the anticipated benefits in practice, then the country should adopt a "hard peg". However, a hypothesis that has not been fully discussed in the literature is that in order to have some of the benefits of a flexible exchange rate arrangement, it is first necessary to have a relatively low and stable inflation rate. Taylor (2000) suggests that the level of exchange rate pass-through

\footnotetext{
4 For more on the relationship between balance sheet effects, the exchange rate regime and macroeconomic performance,
} see Cespedes et al (2000). 
declines the lower the level of inflation, mainly because the pricing power of firms declines as well. Therefore, under this hypothesis it might be possible, specially for emerging market countries, to experience a transition period, from high and unstable inflation environments to low and stable ones, during which the full benefits of a floating regime might not be present. However, once inflation stabilises at low levels, the pass-through weakens and movements of the exchange rate put less pressure on inflation, allowing the economy to fully benefit from the flexible exchange rate.

In a recent study, Choudhri and Hakura (2001) explore the Taylor hypothesis using cross-sectional evidence from 71 countries. Their results support the hypothesis that the level of exchange rate passthrough depends on the inflation environment, since they find that lower levels of exchange rate passthrough are associated with lower levels of average inflation. However, attention is focused on the performance of the exchange rate pass-through over time for only a few countries. In another study, Goldfajn and Werlang (2000) analyse the determinants of the exchange rate pass-through, also in a sample of 71 countries, and find that for developing countries real exchange rate misalignments are the most important determinant of the pass-through, although the output gap plays an important part as well. However, for developed economies they find that the initial rate of inflation is the most important determinant of the exchange rate pass-through. The main focus of the study is on the determinants of the exchange rate pass-through but, again, not on the performance of this passthrough over time. Finally, another recent paper which analyses the determinants of the exchange rate pass-through is by Campa and Goldberg (2002). Their analysis goes beyond testing the influence of macroeconomic variables on the exchange rate pass-through. They find, for a sample of 25 OECD countries, that while the inflation level and exchange rate volatility are weakly associated with higher exchange rate pass-through to import prices, its most important determinants are microeconomic and related to the industry composition of a country's import bundle. Again, in this paper the performance of the exchange rate pass-through over time is not analysed in detail.

The purpose in this paper is to show that the level of the exchange rate pass-through changes over time with the inflation environment. Thus, the emphasis here is precisely to document the behaviour of the pass-through over episodes characterised by different inflation environments. ${ }^{5}$ Then, some of the determinants of the exchange rate pass-through are also analysed to deepen the hypothesis that the pass-through from the exchange rate to prices depends on the inflation environment.

\subsection{Selection of countries}

In order to support or reject the hypothesis that the exchange rate pass-through depends on the inflation environment, the analysis includes the experience of small open economies that satisfy two important criteria. First, they must have flexible exchange rates, so that results can shed some light in the discussion currently taking place in emerging market economies on whether flexible or fixed exchange rate regimes are preferable. Second, these countries must have experienced an inflation reduction process over the last 20 years, so that the analysis can cover both "high" and "low" inflation episodes for each country.

Following these criteria, the analysis includes 16 countries. This group is obviously not exhaustive; however, it is representative since their record includes a variety of episodes which enrich the robustness of the analysis. Colombia, the Czech Republic, Hungary, Mexico, Peru and Poland are emerging market economies in the process of consolidating price stability. Australia and New Zealand succeeded in consolidating their inflation reduction process under flexible exchange rate arrangements and are considered today as "pure floaters". Finally, Canada, Finland, France, Italy, Norway, Portugal, Spain and Sweden represent small open developed economies with close links to the business cycle of large industrialised economies such as the United States and the European Union.

Table 1 shows that the economies included in the analysis are small open economies. With respect to size, Canada is the largest while Peru and Hungary are the smallest. In terms of export and import shares of GDP, most countries seem to be in similar ranges, the Czech Republic and Hungary having

5 In the case of Mexico, Santaella (2002) estimates and compares the exchange rate pass-through between two overlapping
periods (1969-2000 versus 1996-2000). However, that paper makes no explicit comment on the relationship between its periods (1969-2000 versus $1996-2000)$. However,
results and the inflation environment of each period. 
the highest shares and Peru and Colombia the smallest. It is also interesting to note similar magnitudes of net exports across all countries.

\section{Table 1}

\section{GDP and trade shares}

Average for the 1990s

\begin{tabular}{l|c|c|c}
\hline \multicolumn{1}{c|}{ Country } & $\begin{array}{c}\text { GDP } \\
\text { (in billions of USD) }\end{array}$ & $\begin{array}{c}\text { Exports } \\
\text { (as a percentage of GDP) }\end{array}$ & $\begin{array}{c}\text { Imports } \\
\text { (as a percentage of GDP) }\end{array}$ \\
\hline Australia & 350.4 & 18.6 & 19.5 \\
Canada & 596.5 & 34.9 & 33.1 \\
Colombia & 73.8 & 16.1 & 19.6 \\
Czech Republic & 12.4 & 55.8 & 57.6 \\
Finland & 29.8 & 33.8 & 28.4 \\
France & 340.2 & 18.6 & 17.7 \\
Hungary & 11.6 & 48.0 & 49.5 \\
Italy & 284.0 & 23.0 & 20.3 \\
Mexico & 361.8 & 26.8 & 28.1 \\
New Zealand & 13.0 & 29.6 & 28.6 \\
Norway & 34.6 & 39.8 & 33.2 \\
Peru & 11.6 & 13.4 & 17.5 \\
Poland & 36.4 & 26.1 & 29.9 \\
Portugal & 23.2 & 21.3 & 32.4 \\
Spain & 136.4 & 22.2 & 22.9 \\
Sweden & 58.3 & 37.2 & 32.4 \\
\hline
\end{tabular}

Source: IMF.

\subsection{Sample periods}

As mentioned before, the purpose of the paper is to show that the level of exchange rate pass-through is related to the inflation environment of the economy and that through time, as the inflation environment changes, the pass-through varies as well. In this exercise the level of inflation is used to describe the inflation environment and, later, additional variables will be considered to complement the analysis. For the purpose of this exercise a cross-sectional analysis is not adequate, since the level of the passthrough depends on the inflation environment as well as on other country-specific factors, so that a cross-country comparison could lead to erroneous conclusions if all of these factors are not considered in the exercise. For example, if the pass-through is higher in a country with higher inflation, it would be wrong to conclude that this result supports the hypothesis of the inflation environment influencing the level of pass-through, since each country has idiosyncratic elements which affect the result. Therefore, the appropriate comparison should be between a period with "high" inflation and a period with "low" inflation for the same country. ${ }^{6}$ On this basis, the exercise would show that for that country the hypothesis holds. Thus, the inclusion of several countries in the analysis is intended to show how robust

6 It is also possible that period-idiosyncratic elements other than the inflation environment, such as random shocks, may affect the result. 
the results are, but not to directly support or reject the hypothesis tested. This is achieved by comparing for each country the exchange rate pass-through in the "high" inflation period with that of the "low" inflation period.

To analyse the behaviour of the pass-through over time, it is necessary to have at least two sample periods for each country, one that will be labelled as "high" and the other as "low" inflation. In this respect it is important to mention that "high" inflation only means that the average inflation experienced in that period is higher than that observed in the "low" inflation period. However, it is possible for the "low" inflation rate of one country to be higher than the "high" inflation rate of another country. Again, the comparison across countries is not the key element of this exercise.

For most of the countries considered in the analysis, data from the IMF are available from $1976{ }^{7}$ However, some of these economies have experienced hyperinflation or triple digit inflation episodes after 1976. To avoid the influence that these extreme episodes may have on the results, the first criterion for selecting a sample period is that the annual inflation rate must be below $30 \%$. Once the hyperinflation episodes have been ruled out, the second criterion is to divide the sample into "high" and "low" inflation periods. ${ }^{8}$ In doing so, the purpose is to have two different periods that represent different inflation environments for the same country. That will allow for a proper characterisation of the results, one from a "high" inflation period against one from the "low" inflation episode. Thus, the criterion used is to divide the sample when the difference in average inflation between periods is the largest.

Graph 1 shows the sample periods defined for the countries included in the analysis and illustrates the criteria just explained above. Inflation is computed using consumer price indices from the IMF International Financial Statistics. Consider, for example, the case of Colombia, where the thick line represents the annual inflation rate. The thin line shows for every specific date the difference between the average inflation rate during the years immediately prior to the current date and the average inflation rate during the immediate subsequent years. Thus, when the thin line reaches a maximum, it indicates that the difference in the inflation rate before and after that date is maximised. ${ }^{9}$ In the case of Colombia the sample starts in April 1994, because from this point on the inflation rate consistently remained below 30\%, and the differential line (thin) reaches a maximum in March 1999 (vertical line). Therefore, the "high" inflation period for Colombia is defined as extending from April 1994 to March 1999 and the "low" inflation period from April 1999 to December 2001. In the case of Canada, instead of dividing the sample into two periods, three periods ("high", "medium" and "low" inflation) are selected based on the performance of the inflation rate and on the two peaks shown by the differential line. In the cases of Finland, Hungary, Mexico, Peru and Portugal the maximum difference is found at the beginning of the sample, which clearly does not leave enough observations for the "high" inflation period. Therefore, in these cases the second maximum difference is taken to define the "high" and "low" inflation periods.

A quick overview of the inflation and exchange rate performance in the selected sample periods is presented in Table 2. According to the criteria used to select the sample periods, average inflation is considerably higher (at least twice the level for the "low" inflation episodes) for the periods of "high" inflation. To document the performance of the nominal exchange rate during the sample periods, the nominal effective exchange rate (NEER) from the IMF International Financial Statistics is used. It is interesting to note that there is not a clear relationship between average depreciation and average inflation. In some cases the average depreciation is lower in the "low" inflation period while in others it is lower for the "high" inflation episodes. This suggests that the effect of exchange rate depreciations on inflation does not necessarily depend on whether the exchange rate varies nor on the magnitude of its variations.

For Australia and New Zealand data are quarterly while for the other countries they are monthly. Given that Finland, France, Italy, Portugal and Spain joined European monetary union in 1999, their sample periods end in 1998.

8 Choudhri and Hakura (2001) define high-inflation episodes as those where average inflation is higher than $30 \%$, episodes of moderate inflation as those where average inflation is between 10 and $30 \%$, and episodes of low inflation as those where average inflation is below $10 \%$.

9 The number of years considered to compute the moving average inflation before and after a specific date is four. However, results are robust when the number of years considered is either two or six. In the cases of Poland and Hungary the number of years considered to compute the moving average inflation before and after a specific date is one because of the sample size. 
Another interesting feature is that, for all countries, the average exchange rate depreciation is smaller than the average inflation rate during the "high" inflation periods. This result is in line with the "fear of floating" criticism of flexible exchange rate arrangements. However, for Canada, Colombia and Peru, once inflation is reduced ("low" inflation periods), the average exchange rate depreciation is larger than the average inflation rate. These cases suggest that the "fear of floating" phenomenon is not necessarily a characteristic of small open economies with flexible exchange rate arrangements.

Graph 1

\section{Inflation episodes}

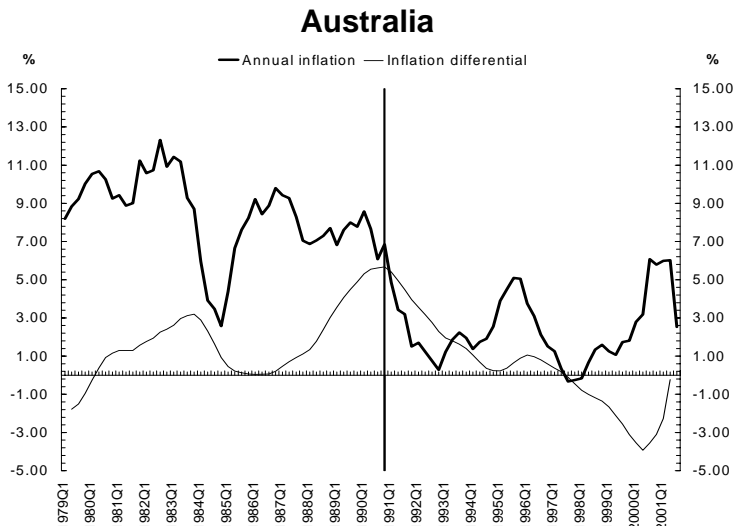

\section{Colombia}

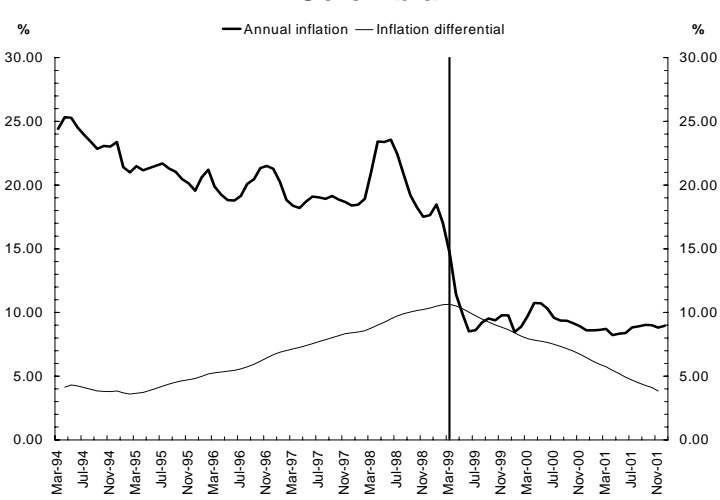

Finland

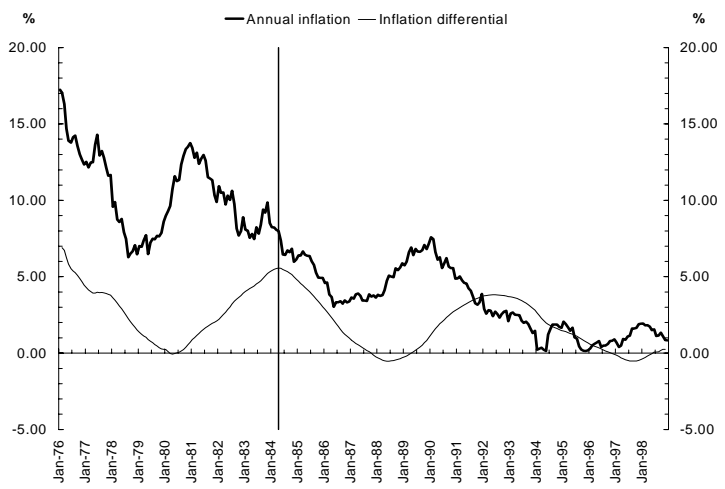

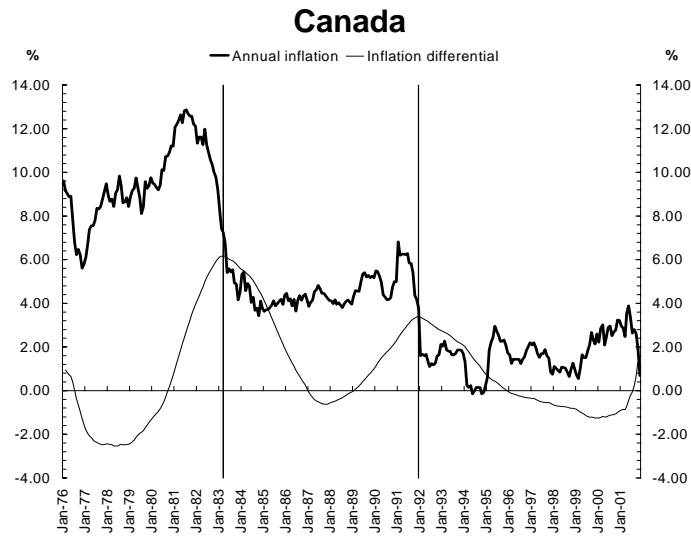

Czech Republic

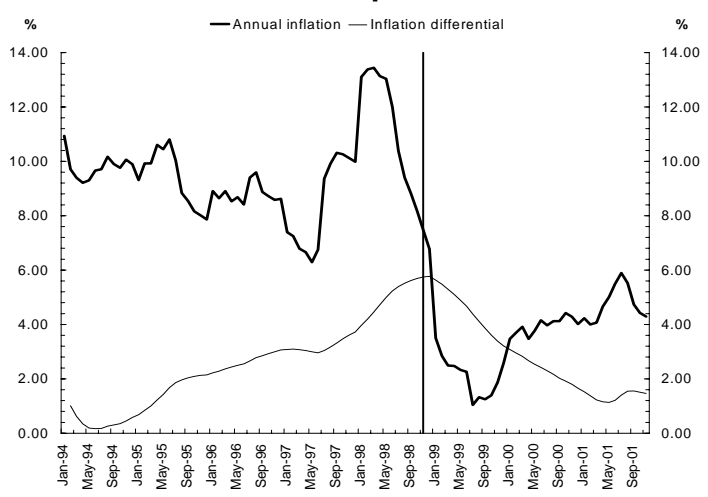

France

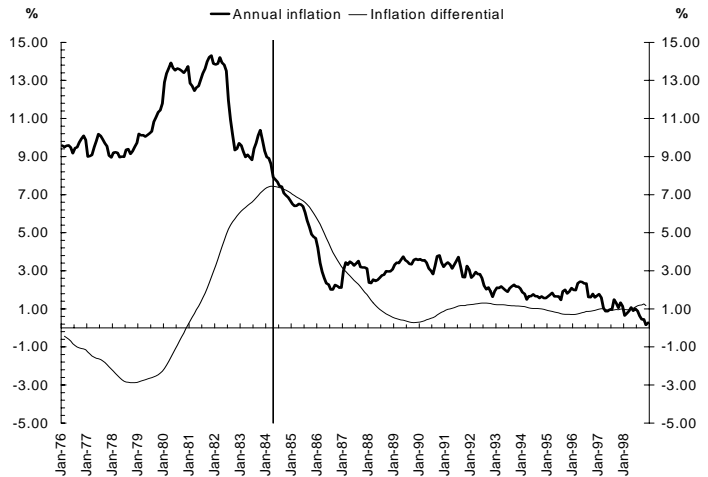


Graph 1 (cont)

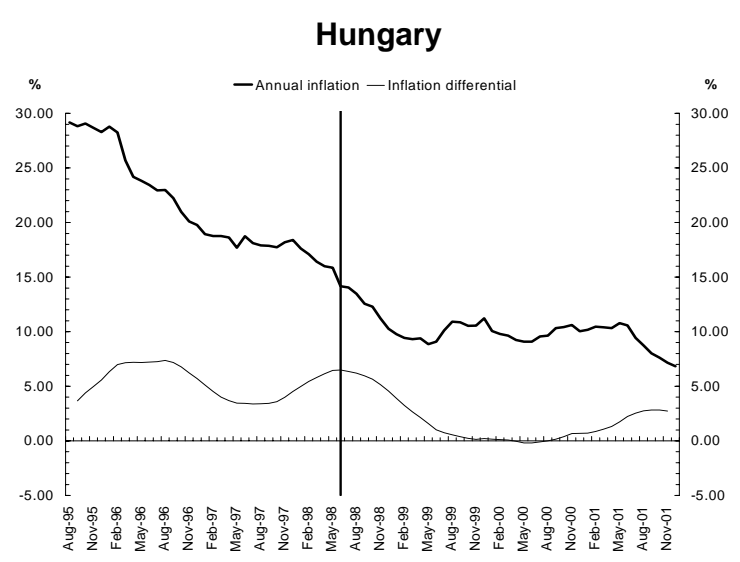

Mexico
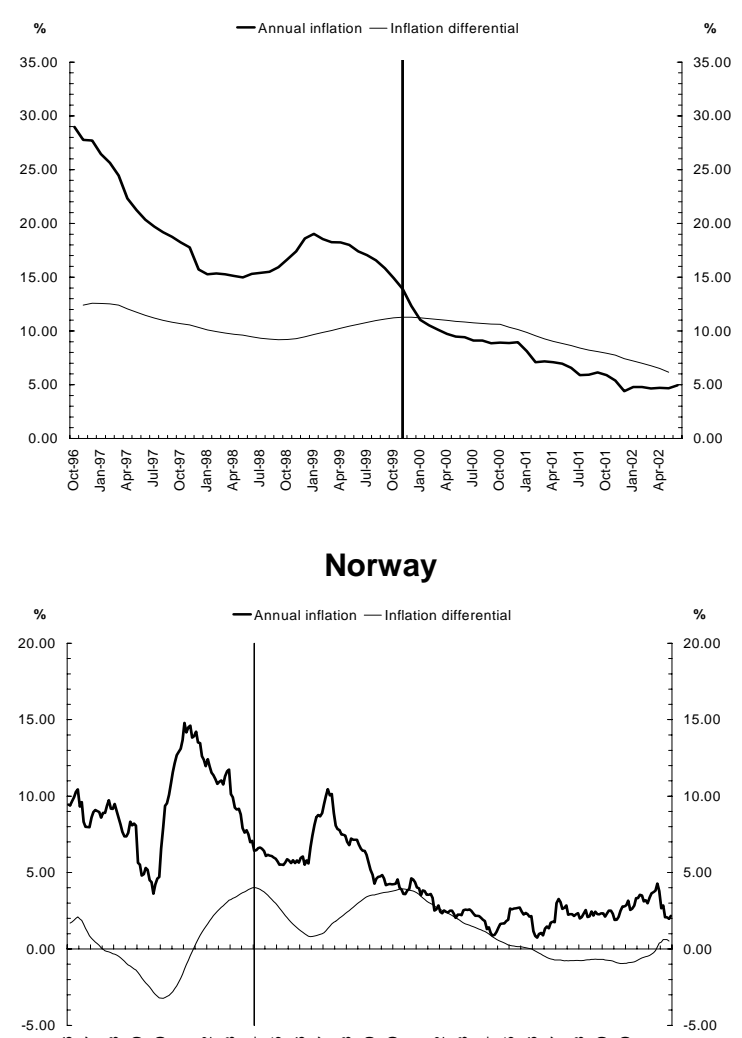

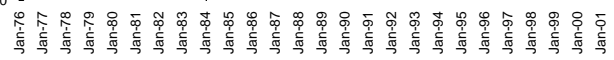

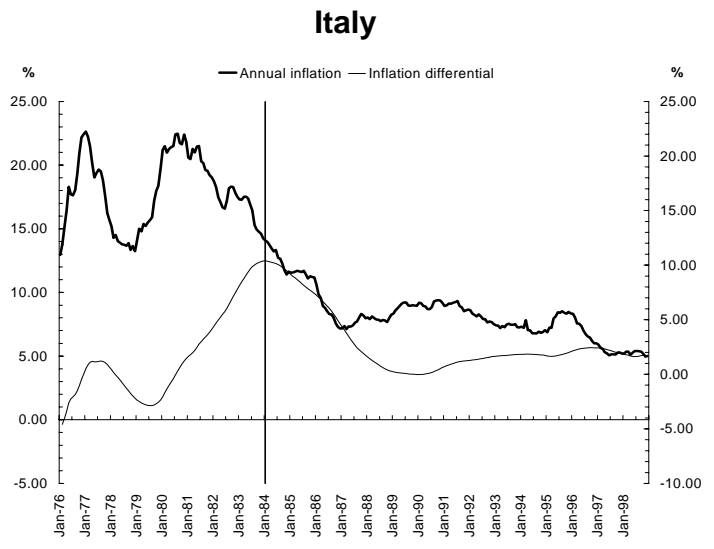

New Zealand

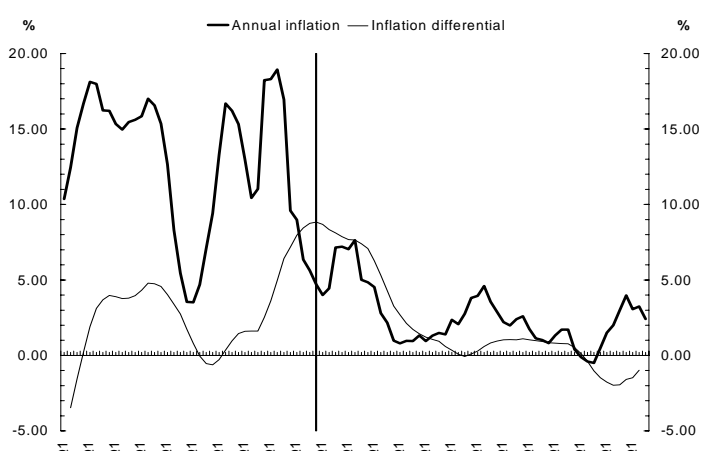

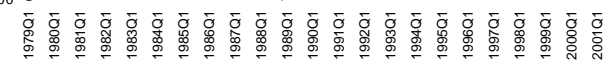

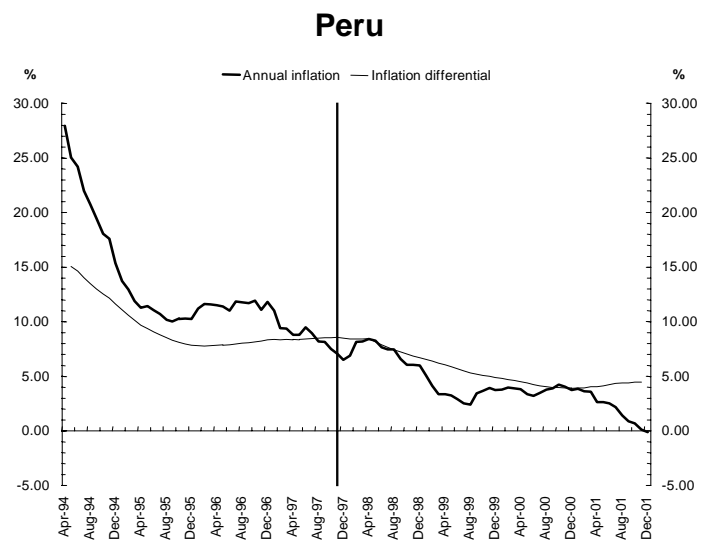


Poland

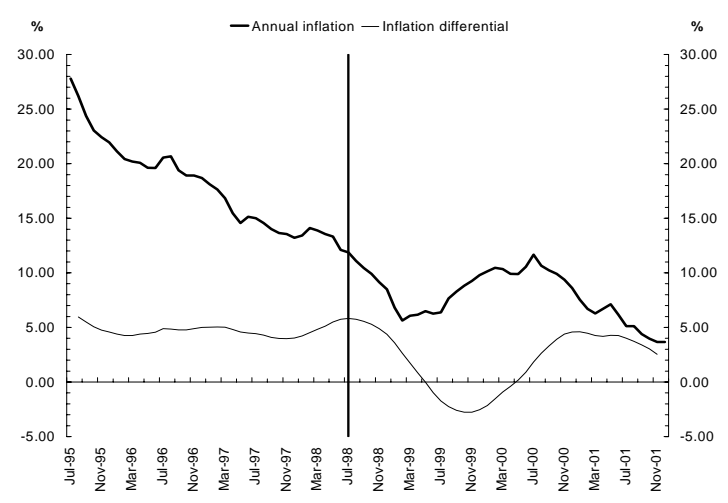

Spain

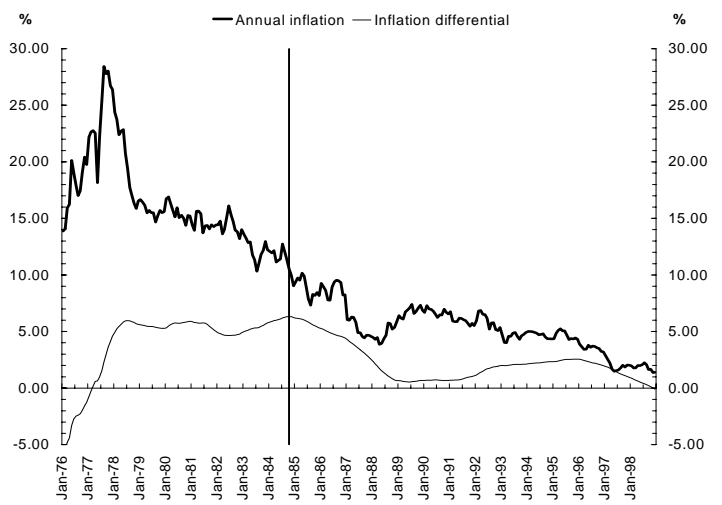

Portugal

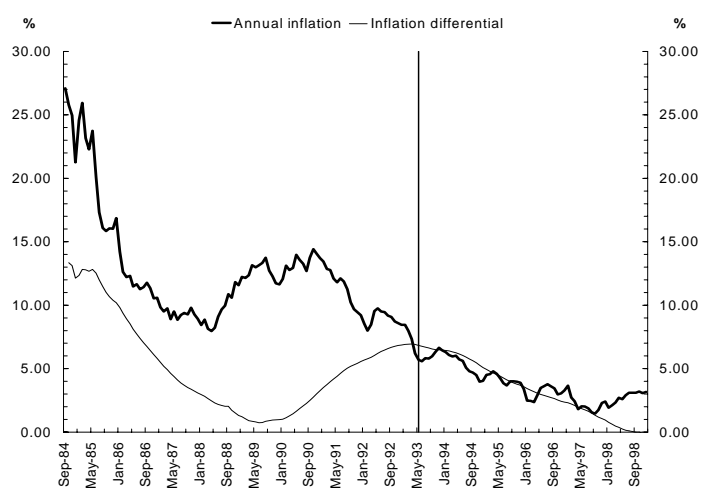

Sweden

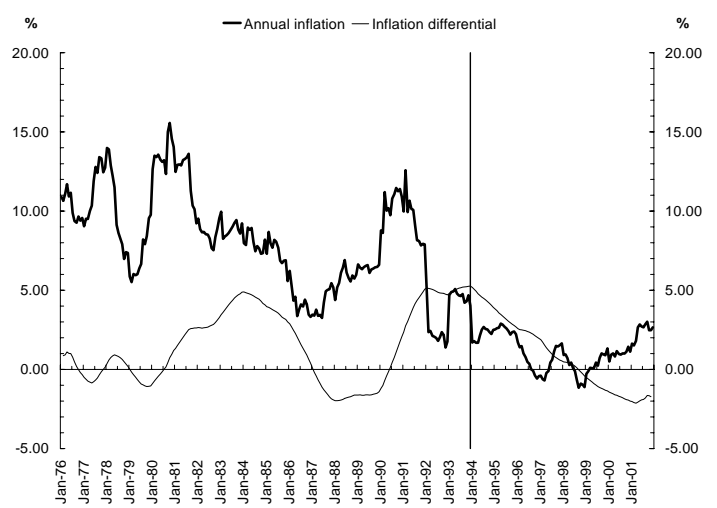

\subsection{Pass-through estimation}

The theoretical framework used as background is found in De Brouwer and Ericsson (1995), which assumes the price level as a Cobb-Douglas function on the price of inputs such as the exchange rate and wages. However, due to the lack of data on wages for some of the periods and countries considered, the exchange rate pass-through is estimated following Hausmann et al (2000). The relationship between prices and the exchange rate is estimated using an OLS estimation of the following equation:

$\ln p_{t}=\beta_{0}+\beta_{1} \ln e r_{t}+\varepsilon_{t}$

In this case $\left(\beta_{1}\right)$ represents the level of pass-through from the exchange rate to prices but because of the omission of wages (and other input prices as well) it is possible that this coefficient will be upwardly biased, ie the estimated level of exchange rate pass-through will be higher than it actually is. ${ }^{10}$ However, for the purpose of the exercise this is not a problem since the idea is to compare the evolution of the exchange rate pass-through across different periods and not to estimate the precise level. In other words, conclusions will be drawn from changes in the coefficient $\beta_{1}$ over time and not from the level of the coefficient.

10 In a strict sense, the magnitude of the bias in the coefficient depends on the relationship between prices, wages and other variables that influence prices such as public and international prices. 


\section{Table 2}

Description of inflation episodes

\begin{tabular}{|c|c|c|c|c|c|}
\hline \multicolumn{2}{|c|}{ Country and "type" of inflation } & \multicolumn{2}{|c|}{$\begin{array}{l}\text { Sample period } \\
\text { (months: 1-12; } \\
\text { quarters: I-IV) }\end{array}$} & \multirow{2}{*}{$\begin{array}{c}\begin{array}{c}\text { Average annual } \\
\text { inflation rate }\end{array} \\
\ln p\end{array}$} & \multirow{2}{*}{$\begin{array}{l}\text { Average annual } \\
\text { variation of nominal } \\
\text { exchange rate }{ }^{1}\end{array}$} \\
\hline & & From & To & & \\
\hline Australia & $\begin{array}{l}\text { "High" } \\
\text { "Low" }\end{array}$ & $\begin{array}{l}\text { 1979: I } \\
\text { 1991: I }\end{array}$ & $\begin{array}{l}\text { 1990: IV } \\
\text { 2001: III }\end{array}$ & $\begin{array}{l}8.02 \\
2.36\end{array}$ & $\begin{array}{l}0.70 \\
1.03\end{array}$ \\
\hline Canada & $\begin{array}{l}\text { "High" } \\
\text { "Medium" } \\
\text { "Low" }\end{array}$ & $\begin{array}{l}\text { 1976:01 } \\
\text { 1983:04 } \\
1992: 01\end{array}$ & $\begin{array}{l}1983: 03 \\
1991: 12 \\
2001: 11\end{array}$ & $\begin{array}{l}9.51 \\
4.59 \\
1.70\end{array}$ & $\begin{array}{r}2.37 \\
-0.19 \\
2.70\end{array}$ \\
\hline Colombia & $\begin{array}{l}\text { "High" } \\
\text { "Low" }\end{array}$ & $\begin{array}{l}\text { 1994:03 } \\
\text { 1999:04 }\end{array}$ & $\begin{array}{l}\text { 1999:03 } \\
2001: 12\end{array}$ & $\begin{array}{r}20.57 \\
9.22\end{array}$ & $\begin{array}{r}6.39 \\
11.77\end{array}$ \\
\hline $\begin{array}{l}\text { Czech } \\
\text { Republic }\end{array}$ & $\begin{array}{l}\text { "High" } \\
\text { "Low" }\end{array}$ & $\begin{array}{l}\text { 1994:01 } \\
\text { 1999:01 }\end{array}$ & $\begin{array}{l}1998: 12 \\
2001: 12\end{array}$ & $\begin{array}{l}9.44 \\
3.59\end{array}$ & $\begin{array}{l}-0.26 \\
-1.98\end{array}$ \\
\hline Finland & $\begin{array}{l}\text { "High" } \\
\text { "Low" }\end{array}$ & $\begin{array}{l}1976: 01 \\
1984: 05\end{array}$ & $\begin{array}{l}1984: 04 \\
1998: 12\end{array}$ & $\begin{array}{l}9.83 \\
3.25\end{array}$ & $\begin{array}{l}1.11 \\
0.94\end{array}$ \\
\hline France & $\begin{array}{l}\text { "High" } \\
\text { "Low" }\end{array}$ & $\begin{array}{l}1976: 01 \\
1984: 04\end{array}$ & $\begin{array}{l}1984: 03 \\
1998: 12\end{array}$ & $\begin{array}{r}10.29 \\
2.77\end{array}$ & $\begin{array}{r}3.57 \\
-0.65\end{array}$ \\
\hline Hungary & $\begin{array}{l}\text { "High" } \\
\text { "Low" }\end{array}$ & $\begin{array}{l}\text { 1995:08 } \\
1998: 07\end{array}$ & $\begin{array}{l}\text { 1998:06 } \\
2001: 12\end{array}$ & $\begin{array}{l}21.26 \\
10.04\end{array}$ & $\begin{array}{r}13.18 \\
4.47\end{array}$ \\
\hline Italy & $\begin{array}{l}\text { "High" } \\
\text { "Low" }\end{array}$ & $\begin{array}{l}1976: 01 \\
1984: 02\end{array}$ & $\begin{array}{c}1984: 01 \\
1998: 12\end{array}$ & $\begin{array}{r}16.70 \\
5.40\end{array}$ & $\begin{array}{l}7.39 \\
2.43\end{array}$ \\
\hline Mexico & $\begin{array}{l}\text { "High" } \\
\text { "Low" }\end{array}$ & $\begin{array}{l}1996: 10 \\
1999: 12\end{array}$ & $\begin{array}{l}1999: 11 \\
2002: 06\end{array}$ & $\begin{array}{r}18.76 \\
7.47\end{array}$ & $\begin{array}{r}8.55 \\
-1.25\end{array}$ \\
\hline New Zealand & $\begin{array}{l}\text { "High" } \\
\text { "Low" }\end{array}$ & $\begin{array}{l}\text { 1979: I } \\
\text { 1989: I }\end{array}$ & $\begin{array}{l}\text { 1988: IV } \\
\text { 2001: III }\end{array}$ & $\begin{array}{r}11.85 \\
2.51\end{array}$ & $\begin{array}{l}4.11 \\
1.96\end{array}$ \\
\hline Norway & $\begin{array}{l}\text { "High" } \\
\text { "Low" }\end{array}$ & $\begin{array}{l}1976: 01 \\
1984: 02\end{array}$ & $\begin{array}{l}1984: 01 \\
2001: 12\end{array}$ & $\begin{array}{l}8.98 \\
3.76\end{array}$ & $\begin{array}{l}0.14 \\
1.10\end{array}$ \\
\hline Peru & $\begin{array}{l}\text { "High" } \\
\text { "Low" }\end{array}$ & $\begin{array}{l}\text { 1994:04 } \\
1997: 12\end{array}$ & $\begin{array}{l}1997: 11 \\
2001: 12\end{array}$ & $\begin{array}{r}12.72 \\
4.17\end{array}$ & $\begin{array}{l}6.80 \\
7.27\end{array}$ \\
\hline Poland & $\begin{array}{l}\text { "High" } \\
\text { "Low" }\end{array}$ & $\begin{array}{l}\text { 1995:07 } \\
\text { 1998:08 }\end{array}$ & $\begin{array}{l}\text { 1998:07 } \\
2001: 12\end{array}$ & $\begin{array}{r}17.78 \\
7.92\end{array}$ & $\begin{array}{r}7.01 \\
-0.21\end{array}$ \\
\hline Portugal & $\begin{array}{l}\text { "High" } \\
\text { "Low" }\end{array}$ & $\begin{array}{l}\text { 1984:09 } \\
1993: 04\end{array}$ & $\begin{array}{l}\text { 1993:03 } \\
\text { 1998:12 }\end{array}$ & $\begin{array}{r}11.68 \\
3.73\end{array}$ & $\begin{array}{l}4.60 \\
1.90\end{array}$ \\
\hline Spain & $\begin{array}{l}\text { "High" } \\
\text { "Low" }\end{array}$ & $\begin{array}{l}\text { 1976:01 } \\
1984: 11\end{array}$ & $\begin{array}{l}\text { 1984:10 } \\
1998: 12\end{array}$ & $\begin{array}{r}16.32 \\
5.37\end{array}$ & $\begin{array}{l}6.29 \\
1.53\end{array}$ \\
\hline Sweden & $\begin{array}{l}\text { "High" } \\
\text { "Low" }\end{array}$ & $\begin{array}{l}\text { 1976:01 } \\
\text { 1994:01 }\end{array}$ & $\begin{array}{l}1993: 12 \\
2001: 12\end{array}$ & $\begin{array}{l}8.06 \\
1.19\end{array}$ & $\begin{array}{l}3.23 \\
1.09\end{array}$ \\
\hline
\end{tabular}

Results of the estimated pass-through coefficient $\left(\beta_{1}\right)$ are reported in Table $3 .{ }^{11}$ Given that the variables are defined in levels, the LR test statistic from the Johansen cointegration test is reported for

11 For all countries, consumer price indices are seasonally adjusted and the exchange rate is defined as the nominal effective exchange rate expressed in units of domestic currency per unit of foreign currency. 
two and 12 lags. ${ }^{12}$ The evidence rejects the null hypothesis of no cointegration between prices and the exchange rate for two lags and, in most of the cases, for 12 lags.

Table 3

Exchange rate pass-through

\begin{tabular}{|c|c|c|c|c|c|c|}
\hline \multirow{3}{*}{\multicolumn{2}{|c|}{ Country and "type" of inflation }} & \multicolumn{2}{|c|}{$\begin{array}{l}\text { Sample period } \\
\text { (months: 1-12; } \\
\text { quarters: I-IV) }\end{array}$} & \multirow{3}{*}{$\begin{array}{l}\text { Pass-through } \\
\text { coefficient }\left(\beta_{1}\right)\end{array}$} & \multicolumn{2}{|c|}{$\begin{array}{c}\text { Johansen } \\
\text { cointegration test }\end{array}$} \\
\hline & & \multirow{2}{*}{ From } & \multirow{2}{*}{ To } & & & \\
\hline & & & & & $\begin{array}{c}1-2 \\
\text { lags }(L R)\end{array}$ & $\begin{array}{c}1-12 \\
\text { lags (LR) }\end{array}$ \\
\hline Australia & $\begin{array}{l}\text { "High" } \\
\text { "Low" }\end{array}$ & $\begin{array}{l}\text { 1979: I } \\
\text { 1991: I }\end{array}$ & $\begin{array}{l}\text { 1990: IV } \\
\text { 2001: III }\end{array}$ & $\begin{array}{l}1.27^{1} \\
0.19\end{array}$ & $30.92^{2}$ & $14.19^{3}$ \\
\hline Canada & $\begin{array}{l}\text { "High" } \\
\text { "Medium" } \\
\text { "Low" }\end{array}$ & $\begin{array}{l}1976: 01 \\
1983: 04 \\
1992: 01\end{array}$ & $\begin{array}{l}1983: 03 \\
1991: 12 \\
2001: 11\end{array}$ & $\begin{array}{r}1.34^{1} \\
-0.51^{1} \\
0.54^{1}\end{array}$ & $33.88^{2}$ & $21.06^{2}$ \\
\hline Colombia & $\begin{array}{l}\text { "High" } \\
\text { "Low" }\end{array}$ & $\begin{array}{l}\text { 1994:03 } \\
\text { 1999:04 }\end{array}$ & $\begin{array}{l}\text { 1999:03 } \\
2001: 12\end{array}$ & $\begin{array}{l}2.56^{1} \\
0.77^{1}\end{array}$ & $31.20^{2}$ & $25.91^{2}$ \\
\hline $\begin{array}{l}\text { Czech } \\
\text { Republic }\end{array}$ & $\begin{array}{l}\text { "High" } \\
\text { "Low" }\end{array}$ & $\begin{array}{l}\text { 1994:01 } \\
\text { 1999:01 }\end{array}$ & $\begin{array}{l}1998: 12 \\
2001: 12\end{array}$ & $\begin{array}{c}0.61 \\
-0.59^{1}\end{array}$ & $17.76^{2,4}$ & 7.62 \\
\hline Finland & $\begin{array}{l}\text { "High" } \\
\text { "Low" }\end{array}$ & $\begin{array}{l}1976: 01 \\
1984: 05\end{array}$ & $\begin{array}{l}\text { 1984:04 } \\
1998: 12\end{array}$ & $\begin{array}{l}1.02^{1} \\
0.01\end{array}$ & $54.88^{2}$ & $19.63^{2}$ \\
\hline France & $\begin{array}{l}\text { "High" } \\
\text { "Low" }\end{array}$ & $\begin{array}{l}1976: 01 \\
1984: 04\end{array}$ & $\begin{array}{l}\text { 1984:03 } \\
1998: 12\end{array}$ & $\begin{array}{r}2.05^{1} \\
-0.01\end{array}$ & $25.12^{2}$ & $17.92^{2}$ \\
\hline Hungary & $\begin{array}{l}\text { "High" } \\
\text { "Low" }\end{array}$ & $\begin{array}{l}1995: 08 \\
1998: 07\end{array}$ & $\begin{array}{l}\text { 1998:06 } \\
2001: 12\end{array}$ & $\begin{array}{l}1.03^{1} \\
0.77^{1}\end{array}$ & $22.02^{2}$ & 10.67 \\
\hline Italy & $\begin{array}{l}\text { "High" } \\
\text { "Low" }\end{array}$ & $\begin{array}{l}1976: 01 \\
1984: 02\end{array}$ & $\begin{array}{l}1984: 01 \\
1998: 12\end{array}$ & $\begin{array}{l}2.09^{1} \\
0.59^{1}\end{array}$ & $33.07^{2}$ & 7.56 \\
\hline Mexico & $\begin{array}{l}\text { "High" } \\
\text { "Low" }\end{array}$ & $\begin{array}{l}1996: 10 \\
1999: 12\end{array}$ & $\begin{array}{l}\text { 1999:11 } \\
2002: 06\end{array}$ & $\begin{array}{r}1.35^{1} \\
-0.48\end{array}$ & $26.84^{2}$ & $34.14^{2}$ \\
\hline New Zealand & $\begin{array}{l}\text { "High" } \\
\text { "Low" }\end{array}$ & $\begin{array}{l}\text { 1979: I } \\
\text { 1989: I }\end{array}$ & $\begin{array}{l}\text { 1988: IV } \\
\text { 2001: III }\end{array}$ & $\begin{array}{l}1.98^{1} \\
0.08\end{array}$ & $26.66^{2}$ & $17.04^{2,3}$ \\
\hline Norway & $\begin{array}{l}\text { "High" } \\
\text { "Low" }\end{array}$ & $\begin{array}{l}\text { 1976:01 } \\
1984: 02\end{array}$ & $\begin{array}{l}1984: 01 \\
2001: 12\end{array}$ & $\begin{array}{l}1.05^{1} \\
0.25^{1}\end{array}$ & $36.27^{2}$ & 13.62 \\
\hline Peru & $\begin{array}{l}\text { "High" } \\
\text { "Low" }\end{array}$ & $\begin{array}{l}1994: 04 \\
1997: 12\end{array}$ & $\begin{array}{l}1997: 11 \\
2001: 12\end{array}$ & $\begin{array}{l}1.94^{1} \\
0.70^{1}\end{array}$ & $31.93^{2}$ & 10.64 \\
\hline Poland & $\begin{array}{l}\text { "High" } \\
\text { "Low" }\end{array}$ & $\begin{array}{l}\text { 1995:07 } \\
\text { 1998:08 }\end{array}$ & $\begin{array}{l}\text { 1998:07 } \\
2001: 12\end{array}$ & $\begin{array}{r}1.69^{1} \\
-0.54^{1}\end{array}$ & $16.29^{2}$ & $34.32^{2}$ \\
\hline Portugal & $\begin{array}{l}\text { "High" } \\
\text { "Low" }\end{array}$ & $\begin{array}{l}\text { 1984:09 } \\
\text { 1993:04 }\end{array}$ & $\begin{array}{l}\text { 1993:03 } \\
\text { 1998:12 }\end{array}$ & $\begin{array}{l}2.29^{1} \\
1.36^{1}\end{array}$ & $38.99^{2}$ & $25.07^{2}$ \\
\hline Spain & $\begin{array}{l}\text { "High" } \\
\text { "Low" }\end{array}$ & $\begin{array}{l}1976: 01 \\
1984: 11\end{array}$ & $\begin{array}{l}1984: 10 \\
1998: 12\end{array}$ & $\begin{array}{l}2.24^{1} \\
1.61^{1}\end{array}$ & $86.00^{2}$ & $37.89^{2}$ \\
\hline Sweden & $\begin{array}{l}\text { "High" } \\
\text { "Low" }\end{array}$ & $\begin{array}{l}1976: 01 \\
1994: 01\end{array}$ & $\begin{array}{l}1993: 12 \\
2001: 12\end{array}$ & $\begin{array}{r}1.41^{1} \\
-0.36^{1}\end{array}$ & $44.98^{2}$ & $19.54^{2}$ \\
\hline
\end{tabular}

${ }^{1}$ Statistically significant at the $5 \%$ level. ${ }^{2}$ Rejects the hypothesis of no cointegration vector at the $5 \%$ significance level. ${ }^{3}$ Test includes one to four lags only. ${ }^{4}$ Test includes one lag only.

12 Tests are performed for the complete sample of each country, from the beginning of the "high" period to the end of the "low" period. 
The estimates of the pass-through coefficient for the "high" inflation periods are positive and statistically different from zero, except in the case of the Czech Republic, where it is positive but statistically not different from zero. In all cases, the coefficients for the "low" inflation periods are smaller than the ones found for the "high" inflation periods. ${ }^{13}$ This result is consistent with the hypothesis that the level of exchange rate pass-through varies as the inflation environment changes. Furthermore, it also shows that this level changes over time. Thus, it means that as the inflation rate decreases, the level of exchange rate pass-through weakens, providing more flexibility to monetary policy.

As mentioned before, Goldfajn and Werlang (2000) find that real exchange rate overvaluation as well as the output gap have an influence on the exchange rate pass-through. However, these factors seem to have no influence on the implications of the previous results since the conclusions from Table 3 hold even when the exchange rate pass-through $\left(\beta_{1}\right)$ is estimated while simultaneously controlling for the real exchange rate overvaluation ${ }^{14}$ and for the output gap (results not shown). ${ }^{15}$ Thus, regardless of the performance of the real exchange rate and of the business cycle, the exchange rate passthrough seems to weaken as inflation is reduced.

Also as previously noted, the coefficients of exchange rate pass-through are smaller for the periods of "low" inflation in all cases. To confirm that this result is in line with the hypothesis that low inflation leads to low levels of exchange rate pass-through, it is interesting to clarify the statistical reasons for which the coefficients decreased from one period to the other. The reduction in the pass-through coefficients could occur in either of the following two scenarios: (i) if the covariance between the price level and the exchange rate decreases (numerator of coefficient $\beta_{1}$ ); or (ii) if the variance of the exchange rate increases (denominator of coefficient $\beta_{1}$ ). Clearly, the hypothesis that the exchange rate coefficient weakens as inflation is reduced is not supported if the reduction in the coefficient is explained by an increment in the exchange rate variance. Conversely, if the reduction in the coefficient is the result of a reduction in the covariance between prices and the exchange rate, the hypothesis tested is corroborated.

The decomposition of the exchange rate pass-through coefficient is presented in Table 4. In all cases, the covariance between prices and the exchange rate is higher for the "high" inflation periods. Furthermore, it is also shown that for almost all countries (except for Finland and Norway) the variance of the exchange rate is smaller in the "low" inflation period. Therefore, these results confirm that the reduction in the exchange rate pass-through coefficients is explained by a weaker relationship between prices and the exchange rate. In other words, the smaller covariance shows that low-inflation environments are associated with weaker relationships between the exchange rate and prices and thus impose fewer restrictions on the implementation of monetary policy.

The results presented above are in line with the hypothesis that the level of exchange rate passthrough is affected by the inflation environment. Thus, when evaluating the costs and benefits of a flexible exchange rate regime, it is important to consider the inflation environment. Results suggest that if a country succeeds in reducing inflation, then the exchange rate pass-through is likely to be reduced as well and the traditional benefits of flexible exchange rate arrangements gradually become available.

13 For each country, results from Chow tests (not presented) suggest that the estimated relationship between prices and the exchange rate experienced a structural change in the transition from the "high" to the "low" inflation period. However, since the variables included in the estimation are non-stationary and cointegrated, Chow tests should be treated with caution.

14 The real exchange rate overvaluation is estimated as the log difference between the actual real effective exchange rate (IMF definition) and its Hodrick-Prescott trend.

15 For each country, industrial production is used as an approximation to output. The output gap is estimated as the log difference between actual output and its Hodrick-Prescott trend. 
Table 4

Exchange rate pass-through decomposition

\begin{tabular}{|c|c|c|c|c|c|}
\hline \multicolumn{2}{|c|}{ Country and "type" of inflation } & \multicolumn{2}{|c|}{$\begin{array}{l}\text { Sample period } \\
\text { (months: 1-12; } \\
\text { quarters: I-IV) }\end{array}$} & \multirow{2}{*}{$\begin{array}{l}\text { Exchange rate } \\
\text { variance }\end{array}$} & \multirow{2}{*}{$\begin{array}{l}\text { Exchange rate and } \\
\text { price level covariance }\end{array}$} \\
\hline & & From & To & & \\
\hline Australia & $\begin{array}{l}\text { "High" } \\
\text { "Low" }\end{array}$ & $\begin{array}{l}\text { 1979: I } \\
\text { 1991: I }\end{array}$ & $\begin{array}{l}\text { 1990: IV } \\
\text { 2001: III }\end{array}$ & $\begin{array}{l}0.01951 \\
0.00480\end{array}$ & $\begin{array}{l}0.02484 \\
0.00095\end{array}$ \\
\hline Canada & $\begin{array}{l}\text { "High" } \\
\text { "Medium" } \\
\text { "Low" }\end{array}$ & $\begin{array}{l}1976: 01 \\
1983: 04 \\
1992: 01\end{array}$ & $\begin{array}{l}1983: 03 \\
1991: 12 \\
2001: 11\end{array}$ & $\begin{array}{l}0.00640 \\
0.00307 \\
0.00415\end{array}$ & $\begin{array}{r}0.00863 \\
-0.00158 \\
0.00225\end{array}$ \\
\hline Colombia & $\begin{array}{l}\text { "High" } \\
\text { "Low" }\end{array}$ & $\begin{array}{l}\text { 1994:03 } \\
\text { 1999:04 }\end{array}$ & $\begin{array}{l}1999: 03 \\
2001: 12\end{array}$ & $\begin{array}{l}0.02177 \\
0.00573\end{array}$ & $\begin{array}{l}0.05587 \\
0.00446\end{array}$ \\
\hline $\begin{array}{l}\text { Czech } \\
\text { Republic }\end{array}$ & $\begin{array}{l}\text { "High" } \\
\text { "Low" }\end{array}$ & $\begin{array}{l}\text { 1994:01 } \\
\text { 1999:01 }\end{array}$ & $\begin{array}{l}1998: 12 \\
2001: 12\end{array}$ & $\begin{array}{l}0.00106 \\
0.00088\end{array}$ & $\begin{array}{r}0.00065 \\
-0.00052\end{array}$ \\
\hline Finland & $\begin{array}{l}\text { "High" } \\
\text { "Low" }\end{array}$ & $\begin{array}{l}1976: 01 \\
1984: 05\end{array}$ & $\begin{array}{l}1984: 04 \\
1998: 12\end{array}$ & $\begin{array}{l}0.00290 \\
0.00864\end{array}$ & $\begin{array}{l}0.00297 \\
0.00011\end{array}$ \\
\hline France & $\begin{array}{l}\text { "High" } \\
\text { "Low" }\end{array}$ & $\begin{array}{l}1976: 01 \\
1984: 04\end{array}$ & $\begin{array}{l}1984: 03 \\
1998: 12\end{array}$ & $\begin{array}{l}0.00767 \\
0.00226\end{array}$ & $\begin{array}{r}0.01575 \\
-0.00003\end{array}$ \\
\hline Hungary & $\begin{array}{l}\text { "High" } \\
\text { "Low" }\end{array}$ & $\begin{array}{l}\text { 1995:08 } \\
\text { 1998:07 }\end{array}$ & $\begin{array}{l}1998: 06 \\
2001: 12\end{array}$ & $\begin{array}{l}0.00621 \\
0.00129\end{array}$ & $\begin{array}{l}0.00645 \\
0.00100\end{array}$ \\
\hline Italy & $\begin{array}{l}\text { "High" } \\
\text { "Low" }\end{array}$ & $\begin{array}{l}1976: 01 \\
1984: 02\end{array}$ & $\begin{array}{l}\text { 1984:01 } \\
1998: 12\end{array}$ & $\begin{array}{l}0.02010 \\
0.01978\end{array}$ & $\begin{array}{l}0.04219 \\
0.01179\end{array}$ \\
\hline Mexico & $\begin{array}{l}\text { "High" } \\
\text { "Low" }\end{array}$ & $\begin{array}{l}\text { 1996:10 } \\
\text { 1999:12 }\end{array}$ & $\begin{array}{l}\text { 1999:11 } \\
\text { 2002:06 }\end{array}$ & $\begin{array}{l}0.00916 \\
0.00048\end{array}$ & $\begin{array}{r}0.01243 \\
-0.00023\end{array}$ \\
\hline New Zealand & $\begin{array}{l}\text { "High" } \\
\text { "Low" }\end{array}$ & $\begin{array}{l}\text { 1979: I } \\
\text { 1989: I }\end{array}$ & $\begin{array}{l}\text { 1988: IV } \\
\text { 2001: III }\end{array}$ & $\begin{array}{l}0.02532 \\
0.00786\end{array}$ & $\begin{array}{l}0.05036 \\
0.00067\end{array}$ \\
\hline Norway & $\begin{array}{l}\text { "High" } \\
\text { "Low" }\end{array}$ & $\begin{array}{l}\text { 1976:01 } \\
\text { 1984:02 }\end{array}$ & $\begin{array}{l}1984: 01 \\
2001: 12\end{array}$ & $\begin{array}{l}0.00097 \\
0.00289\end{array}$ & $\begin{array}{l}0.00103 \\
0.00073\end{array}$ \\
\hline Peru & $\begin{array}{l}\text { "High" } \\
\text { "Low" }\end{array}$ & $\begin{array}{l}1994: 04 \\
1997: 12\end{array}$ & $\begin{array}{l}1997: 11 \\
2001: 12\end{array}$ & $\begin{array}{l}0.00582 \\
0.00669\end{array}$ & $\begin{array}{l}0.01131 \\
0.00468\end{array}$ \\
\hline Poland & $\begin{array}{l}\text { "High" } \\
\text { "Low" }\end{array}$ & $\begin{array}{l}1995: 07 \\
1998: 08\end{array}$ & $\begin{array}{l}\text { 1998:07 } \\
2001: 12\end{array}$ & $\begin{array}{l}0.00397 \\
0.00309\end{array}$ & $\begin{array}{r}0.00672 \\
-0.00167\end{array}$ \\
\hline Portugal & $\begin{array}{l}\text { "High" } \\
\text { "Low" }\end{array}$ & $\begin{array}{l}1984: 09 \\
1993: 04\end{array}$ & $\begin{array}{l}\text { 1993:03 } \\
1998: 12\end{array}$ & $\begin{array}{l}0.01118 \\
0.00035\end{array}$ & $\begin{array}{l}0.02569 \\
0.00048\end{array}$ \\
\hline Spain & $\begin{array}{l}\text { "High" } \\
\text { "Low" }\end{array}$ & $\begin{array}{l}\text { 1976:01 } \\
1984: 11\end{array}$ & $\begin{array}{l}1984: 10 \\
1998: 12\end{array}$ & $\begin{array}{l}0.02495 \\
0.00896\end{array}$ & $\begin{array}{l}0.05592 \\
0.01447\end{array}$ \\
\hline Sweden & $\begin{array}{l}\text { "High" } \\
\text { "Low" }\end{array}$ & $\begin{array}{l}\text { 1976:01 } \\
1994: 01\end{array}$ & $\begin{array}{l}1993: 12 \\
2001: 12\end{array}$ & $\begin{array}{l}0.02487 \\
0.00238\end{array}$ & $\begin{array}{r}0.03519 \\
-0.00087\end{array}$ \\
\hline
\end{tabular}

\subsection{Determinants of the exchange rate pass-through}

The evidence presented in the previous subsection shows that the level of the exchange rate passthrough depends on the level of the inflation rate. As inflation decreases, the relationship between prices and the exchange rate weakens. However, it is possible that changes in the inflation environment are not fully described by the level of average inflation, since other variables may have an effect on the pass-through beyond the one already captured by the reduction in the level of inflation. For example, as credibility in price stability rises, it may be possible for the exchange rate passthrough to decrease. Another example is the competitive structure of domestic markets. When a 
market is more competitive, firms are likely to have less flexibility to pass through cost increases to consumers. Thus, in this exercise the analysis goes beyond the effect of the level of inflation on the exchange rate pass-through and tries to identify other determinants which may be associated with changes in the inflation environment.

The analysis in this section follows Choudhri and Hakura (2001) and Campa and Goldberg (2002) in using the results from the pass-through estimation in the previous section to run second-stage regressions over the pass-through coefficients of the following form:

$\beta_{1}^{i j}=\alpha+\phi X^{i j}+\varepsilon^{i j}$

where $\beta_{1}^{i j}$ represents the exchange rate pass-through coefficient from Table 3 for country " $i$ " and for inflation period " $j$ " ("high" or "low" inflation) and $X^{i j}$ represents a vector of regressors which are country ("i") and period (" $j$ ") specific. Thus, the sample in this cross-sectional exercise contains 33 observations. ${ }^{16}$ With such a specification it is possible to test the relationship between variables other than average inflation and the exchange rate pass-through.

Since the pass-through coefficients were estimated for periods with different average inflation, it is necessary to control for this effect so that the results for the other variables are not biased. Therefore, the first regressor to be included is the average inflation rate. Then, by adding additional variables to equation (2), it is possible to test if average inflation alone provides a sufficient description of the inflation environment (ie no other variable has a significant effect on the pass-through coefficient), or if additional variables complement the information contained in the level of inflation and thus, by including them in the analysis, the relationship between prices and the exchange rate is better understood.

Equation (2) is estimated using weighted least squares, where the weights are defined as the inverse of the standard error of the estimated pass-through coefficients from the previous exercise (Table 3 ). The results of the exercise are presented in Table 5. The right-hand regressors included are average inflation, nominal exchange rate volatility (coefficient of variation), the trade balance (net exports) as a percentage of GDP and the average spread between consumer (CPI) and producer (PPI) prices indices.

Table 5

Determinants of exchange rate pass-through

\begin{tabular}{l|c|c|c|c}
\hline \multicolumn{1}{c|}{ Regressor $(\boldsymbol{X})$} & Specification 1 & Specification 2 & Specification 3 & Specification 4 \\
\hline Constant & -0.063 & $-0.826^{1}$ & $-0.487^{1}$ & $-0.323^{1}$ \\
Average inflation & $0.112^{1}$ & $0.074^{1}$ & $0.045^{1}$ & $0.040^{1}$ \\
Exchange rate volatility & & $11.043^{1}$ & $10.056^{1}$ & $8.492^{1}$ \\
Trade balance & & & $-8.902^{1}$ & $-13.178^{1}$ \\
CPI-PPI spread & & & & $-2.244^{1}$ \\
\hline Adjusted R $R^{2}$ & 0.860 & 0.931 & 0.948 & 0.956 \\
Number of observations & 33 & 33 & 33 & $31^{2}$ \\
\hline
\end{tabular}

${ }^{1}$ Statistically significant at the $5 \%$ level. ${ }^{2}$ Portugal omitted due to lack of PPI data.

16 Two periods per country and three for Canada. 
As expected, the coefficient for average inflation is positive and statistically significant. The fact that the coefficients for the other variables are also statistically significant suggests that the inflation environment is not fully described by average inflation. Results suggest that higher exchange rate volatility leads to higher levels of exchange rate pass-through; thus the inflation environment is not only described by the level of nominal variables but also by their volatility. This is consistent with the theoretical results from Devereux and Engel (2001), which show that the level of exchange rate passthrough decreases as nominal variables become more stable since firms wish to set their prices in the currency of the country with the most stable monetary policy. Another result is that larger trade deficits (smaller net exports) lead to higher levels of exchange rate pass-through. This suggests that sound macroeconomic fundamentals, which include sustainable external accounts, are also part of the inflation environment. As the trade deficit increases it becomes more difficult to finance and the probability of an exchange rate depreciation rises, which in turn drives more firms to pass through any exchange rate movement to their prices.

Another interesting result is found with the average spread between CPI and PPI. The effect of this variable is also statistically significant and the negative sign suggests that when the spread between consumer and producer prices is reduced, the pass-through coefficient increases since firms have no room to accommodate a cost increase without passing it on to consumers. On the other hand, a larger spread can be associated with more flexibility in firms to absorb cost increases. This result suggests that an interesting line for further research would be to analyse the process through which firms set their prices, particularly in competitive markets, where, as argued by Rotemberg (2002), the reaction of consumers may be the major concern for a firm when setting prices. In this framework the frequency of price adjustments depends on economy-wide variables observed by consumers (an unstable macroeconomic environment would lead to frequent price changes and higher passthroughs).

Results confirm that the relationship between prices and the exchange rate weakens when inflation is low. A stable macroeconomic framework induces a weaker exchange rate pass-through and thus fosters the benefits of flexible exchange rate arrangements.

\section{Conclusions}

The analysis presented in this paper suggests that the level of the exchange rate pass-through depends on the inflation environment. For a group of small open economies that in recent years have experienced disinflation processes, it is shown that the level of exchange rate pass-through weakens as the level of inflation falls. This result suggests that when a low and stable inflation environment is achieved, agents' expectations are likely to be in line with the authorities' inflation target and thus to be less influenced by short-term exchange rate variations. Under such circumstances it is possible to infer that the "fear of inflation", which any central bank should have, no longer implies a "fear of floating". Credibility in monetary policy as well as competitive markets are likely to be at the heart of this result.

The analysis suggests that the inflation environment should be considered as an important element when evaluating alternative exchange rate regimes. This is likely to be of particular importance for emerging market economies, where low and stable inflation environments are not necessarily the norm. Thus, with respect to the empirical debate between the benefits different economies may attain under a "floating" or a "hard peg" regime, the evidence presented in this paper suggests that the appropriate comparison should be between "hard pegs" and "floats", but only when the "floating" economies have achieved low and stable inflation environments.

In this paper it is argued that a low and stable inflation environment, associated with weaker exchange rate pass-through, is not only described by the level of inflation but also by stability in nominal variables and by the environment in which firms set their prices. Both monetary policy and the structure of markets seem to have an important effect on the relationship between prices and the exchange rate. Understanding the interaction between monetary policy and firms' price setting behaviour would appear to be an interesting exercise in an effort to fully identify the determinants of the exchange rate pass-through. 


\section{References}

Calvo, G and C Reinhart (2002): "Fear of floating", Quarterly Journal of Economics, vol 117, no 2, May.

Campa, J and L Goldberg (2002): "Exchange rate pass-through into import prices: a macro or a micro phenomenon?", National Bureau of Economic Research Working Paper, no 8934, May.

Cespedes, L, R Chang and A Velasco (2000): "Balance sheets and exchange rate policy", National Bureau of Economic Research Working Paper, no 7840, August.

Choudhri, E and D Hakura (2001): "Exchange rate pass-through to domestic prices: does the inflationary environment matter?", IMF Working Paper, no 01/194, December.

De Brouwer, G and N Ericsson (1995): "Modeling inflation in Australia", Reserve Bank of Australia Research Discussion Paper, no 9510.

Devereux, M and C Engel (2001): "Endogenous currency of price setting in a dynamic open economy model", National Bureau of Economic Research Working Paper, no 8559, October.

Edwards, S (1993): "Exchange rates as nominal anchors", Weltwirtschaftliches Archiv, no 1.

(2002a): "Twenty-five years of stabilization programs in Latin America: the exchange rate connection", in Banco de México (ed), Stabilization and monetary policy: the international experience, Mexico.

(2002b): "The great exchange rate debate after Argentina", National Bureau of Economic Research Working Paper, no 9257, October.

Eichengreen, B and R Hausmann (1999): "Exchange rates and financial fragility", National Bureau of Economic Research Working Paper, no 7418, November.

Fischer, S (2001): "Exchange rate regimes: is the bipolar view correct?", Journal of Economic Perspectives, vol 15, no 2.

Ghosh, A, A Gulde and J Ostry (1995): "Does the nominal exchange rate regime matter?", IMF Working Paper, no 95/121, November.

Goldfajn, I and S Werlang (2000): "The pass-through from depreciation to inflation: a panel study", Working Paper Series, no 5, Banco Central do Brasil, September.

Hausmann, R, M Gavin, C Pages and E Stein (1999): "Financial turmoil and the choice of exchange rate regime", Inter-American Development Bank Working Paper, no 400.

Hausmann, R, U Panizza and E Stein (2000): "Why do countries float the way they float?", InterAmerican Development Bank Working Paper, no 418.

International Monetary Fund (1997): "Exchange rate arrangements and economic performance in developing countries", World Economic Outlook, October.

- CD-ROM Data Bases.

Levy-Yeyati, E and F Sturzenegger (2002): To float or to trail: evidence on the impact of exchange rate regimes, Business School, Universidad Torcuatto Di Tella, mimeo, March.

Rotemberg, J (2002): Customer anger at price increases, time variation in the frequency of price changes and monetary policy, mimeo, October.

Santaella, J (2002): "El traspaso inflacionario del tipo de cambio, la paridad del poder de compra y anexas: la experiencia mexicana", in La Inflación en México, Gaceta de Economía, ITAM.

Taylor, J (2000): "Low inflation, pass-through and the pricing power of firms", European Economic Review, vol 44.

Velasco, A (2002): "Exchange rates in emerging markets: floating toward the future", in Banco de México (ed), Stabilization and monetary policy: the international experience, Mexico. 